\title{
\begin{tabular}{l|l|l} 
& Jurnal Kependidikan Dasar & Volume : 5 \\
& Nomor :1 \\
Islam Berbasis Sains & Tahun : 2020
\end{tabular}
}

\section{Nilai-nilai Pendidikan Karakter dalam Novel Assalamualaikum Calon Imam Karya Ima Madaniah}

\author{
Dewi Asiyah Zulfarida dan Siti Isnaniah \\ Tadris Bahasa Indonesia Institut Agama Islam Negeri Surakarta \\ Jalan Pandawa, Pucangan, Kartasura, Sukoharjo \\ Pos-el: dewiasiyahzulfarida@gmail.com
}

\begin{abstract}
ABSTRAK
Penelitian ini bertujuan untuk mendiskripsikan nilai-nilai pendidikan karakter yang terkandung dalam novel Assalamualaikum Calon Imam karya Ima Madaniah yang dianalisis dengan pendekatan sruktural dan nilai-nilai pendidikan karakter. Penelitian ini merupakan penelitian deskriptif kualitatif dengan metode analisis isi content analysis. Teknik keabsahan data menggunakan triangulasi teori. Sumber data berupa novel Assalamualaikum Calon Imam karya Ima Madaniah. Teknik pengumpulan data yang pertama membaca novel Assalamualaikum Calon Imam karya Ima Madaniah secara keseluruhan, kedua mencatat dan menandai data-data yang berhubungan dengan nilainilai pendidikan karakter, ketiga menginventarisasikan data yang berhubungan dengan nilai-nilai pendidikan, keempat mengklasifikasikan data yang terkumpul berdasarkan kajian nilai-nilai pendidikan karakter yang terdapat dalam novel. Teknik analisis data menggunakan model interaktif dengan mendeskripsikan data yang sudah diinventarisasikan, mengklasifikasikan data sesuai dengan teori yang dikemukakan, menganalisis data berdasarkan klasifikasi yang ditemukan, menginterpretasikan data yang sudah dianalisis, menarik simpulan dan menulis laporan penelitian.
\end{abstract}

Kata kunci: Nilai-nilai Pendidikan Karakter, Novel Assalamualaikum Calon Imam.

\section{ABSTRACT}

This study aims to describe the values of character education contained in the novel Assalamualaikum Calon Imam by Ima Madaniah analyzed by structural approaches and values of character education. This research is a qualitative descriptive study with content analysis method. The data validity technique uses theory triangulation. The data source is Assalamualaikum Calon Imam Imam by Ima Madaniah. The first data collection technique reads the novel Assalamualaikum Calon Imam by Ima Madaniah as a whole. the values of character education contained in the novel. Data analysis techniques use an interactive model by describing data that has been inventoried, classifying data according to the theories put forward, analyzing data based on the classification found, interpreting data that has been analyzed, drawing conclusions and writing research reports.

Keywords: Education Character Values, Assalamualaikum Calon Imam Novel. 


\section{PENDAHULUAN}

Ide kepercayaan seseorang dikeluarkan dengan bentuk tulisan yaitu karya sastra. Karya sastra berkaitan dengan manusia dan berkaitan erat antara sastra dengan budaya. Sastra dengan budaya mempunyai fungsi penting dalam kemajuan suatu bangsa, dengan adanya peranan penting tersebut manusia dapat mempelajari ilmu pengetahuan seperti budaya, pandangan hidup, dan adat istiadat di masyarakat dengan menerapkanya dalam kehidupan sehari-hari.

Karya sastra sebagai ragam tulisan mendominasi munculnya unsur estetis, karya sastra mampu memberikan perasan terhadap pembaca. Dari beberapa karya sastra terdapat satu jenis karya sastra yaitu novel. Novel sebagai karya sastra yang menarik dapat dibaca oleh masyarakat umum, terutama dikalangan remaja. Novel menceritakan kehidupan yang terjadi di masyarakat yang mencakup masalah agama, sosial, politik, ekonomi, dan budaya. Kehadiran novel bertujuan untuk mengungkapkan isi cerita dan mengangkat aspek-aspek kehidupan yang dapat diterapkan dalam kehidupan nyata. Terciptanya sebuah novel berasal dari latar belakang pengarang itu sendiri dan tidak terlepas dari kehidupan masyarakat di sekitar.

Stanton ${ }^{1}$ menjelaskan bahwa kehadiran novel dapat menciptakan pertumbuhan moral dari beberapa kejadian munculnya karakter selama betahun-tahun. Sebagai bahan bacaan untuk pembaca, novel sebagai jenis karya fiksi dalam kesastraan kaitanya dengan penceritaan yang paling lengkap. Novel dibedakan menjadi dua kategori yaitu karya hiburan dan karya serius. Semua karya tidak dapat disebut sebagai karya hiburan

\footnotetext{
${ }^{1}$ Stanton, Teori Fiksi, 90.
}

tetapi sebuah novel serius dituntut untuk memberikan karya yang menarik, dapat diterima oleh pembaca dan memberikan hiburan serta dituntut untuk lebih dari itu. Ciri utama novel dapat memotivasi, menghibur, dan menarik bagi pembaca.

Novel menjadi sebuah karya sastra yang berfungsi untuk memberikan motivasi dan inspirasi bagi pembacanya. Karya sastra yang ingin peneliti kaji yaitu novel Assalamualaikum Calon Imam karya Ima Madaniah karena novel ini mengambil latar cerita dari seorang perempuan cantik bernama Nafisya. Kepercayaan sebagai hal yang cukup langka bagi Fisya, penyebab utamanya ia tidak percaya dengan laki-laki terutama dengan ayahnya sendiri. Nafisya juga memiliki perasaan cinta dengan Jidan tetangga sekaligus teman bermainya di masa anak-anak. Pertemanan yang berujung cinta ini tidak bertahan lama, Jidan mencintai wanita lain sebagai tambatan hatinya. Kepercayaan Nafisya dengan laki-laki mulai pudar, seakan merasa putus asa apabila berdekatan dengan pria karena Fisya trauma dengan perceraian orang tuanya.

Cerita di dalam novel Assalamualaikum Calon Imam ini memunculkan nilai pendidikan karakter, seperti nilai religius, suka menolong dan lainya, nilai religius merupakan nilai pendidikan karakter dalam hubunganya dengan Tuhan, suka menolong merupakan tindakan yang berupaya membantu orang lain apabila sedang mengalami kesusahan. Seperti dalam novel ini mengisahkan ketika Fisya bertemu dengan seorang dokter disaat menolong anak kecil terlibat kecelakaan di jalan. Merupakan salah satu nilai pendidikan karakter suka menolong.

Novel karya pengarang bernama Ima Madaniah ini diterbitkan pada tahun 2017 dengan tebal 476 halaman. Melalui ketikan jarinya, Ima Madaniah mampu 
menghidupkan tokoh-tokoh di dalam cerita melalui kosakata yang beragam dan menarik $^{2}$. Bahkan ketika diunggah di dalam situs buku online Wattpad, novel ini telah dibaca lebih dari tiga juta pasang mata. Sehingga novel ini layak difilmkan di bioskop, film yang diadaptasi dari novel Assalamualaikum Calon Imam ini pertama tayang di bioskop pada bulan februari 2018. Penulis novel ini ternyata masih muda dan memiliki hobi menulis kisah-kisah bergenre Islam dan memiliki cita-cita ingin menjadi hafidz Alquran. Ima merasa memiliki sesuatu kebangaan tersendiri untuk bisa membuat jejak kehidupan, menabur hikmah melewati tulisan.

Pembahasan subbagian dalam novel ini dilakukan dengan cara mengupas kecenderungan penggunaan kajian stuktural sehubungan dengan masalah pokok yang sedang dipelajari. Pendekatan strukturalisme memandang karya sastra sebagai pelengkap antarunsur. Analisis struktural memandang suatu karya sebagai penciptaan hubungan antarunsur pembangun karya sastra. Fakta cerita dan sarana sastra sebagai unsur pembangun novel yang menggunakan kajian struktural. Unsur pembangun dalam novel sebagai fakta cerita meliputi alur, latar, karakter, dan tema. berbeda dengan usur pembangun sebagai sarana sastra yang meliputi sudut pandang, judul, simbolisme, ironi, gaya dan tone ${ }^{3}$.

Novel sebagai bahan bacaan bagi kalangan umum di masyarakat berkembang secara pesat dari generasi ke generasi, banyak novel-novel yang sedang merilis dan tidak semua novel terlepas dari unsur pembangun karya sastra

\footnotetext{
${ }^{2}$ Madaniah, Assalamualaikum Calon Imam.

${ }^{3}$ Natalia Sunata, Saddhono, and Hastuti, "TINJAUAN STRUKTURAL DAN NILAI PENDIDIKAN NOVEL BIDADARI-BIDADARI SURGA KARYA TERE LIYE: (Relevansinya Dalam Pembelajaran Di Sekolah Menengah Atas)."
}

karena dengan adanya unsur pembangun novel tersebut memudahkan pembaca untuk mengetahui secara keseluruhan isi yang disampaikan pengarang terhadap pembaca.

Selain kajian struktural, analisis novel ini juga dapat dilakukan dengan mengungkapkan nilai-nilai pendidikan karakter. Menurut Raka ${ }^{4}$ berpendapat bahwa pendidikan karakter sebagai pengembangan moral serta berfikir untuk menanamkan karakter di lingkungan belajar, seperti di lingkungan rumah, lapisan masyarakat, dan sekolah. Kesatuan dalam akhlak manusia disebut pendidikan karakter, sehingga dapat mengembangkan sifat-sifat kemuliaan sebagai makhluk yang taat dan mengembangkan keyakinan serta kesadaran manusia.

Penerapan pendidikan karakter merupakan langkah yang efektif untuk menumbuhkan kejujuran, percaya diri, dan menghargai orang lain. Novel Assalamualaikum Calon Imam karya Ima Madaniah ini bisa menjadi motivasi bagi masyarakat umum dan dapat mengetahui pengetahuan yang lebih mengenai pendidikan karakter yang ada di dalamnya serta meningkatkan minat baca terutama dalam bentuk novel sebaagai pedoman kehidupan.

Berdasarkan pengamatan yang dilakukan penulis. Maka penelitian novel yang dilakukan dengan kajian struktural dan nilai-nilai pendidikan karakter di atas pantas untuk dilakukan penelitian guna memudahkan masyarakat umum untuk memahami makna yang disampaikan oleh pengarang di dalam novel.

\section{METODE}

Jenis penelitian dalam penelitian ini adalah deskriptif kualitatif, dimaksudkan untuk memperoleh

\footnotetext{
${ }^{4}$ Raka et al., Pendidikan Karakter Di Sekolah: Dari Gagasan Ke Tindakan, 258.
} 
informasi mengenai nilai-nilai pendidikan karakter pada novel yang berjudul Assalamualaikum Calon Imam karya Ima Madaniah secara kompleks dan komprehensif. Teknik keabsahan data untuk penelitian ini yaitu menggunakan teknik triangulasi teori. Teknik analisis data untuk penelitian ini yaitu menggunakan teknik kajian struktural. Dalam penelitian ini nilai-nilai pendidikan karakter menggunakan teori Likona untuk menganalisis nilai-nilai pendidikan karakter yang ada pada novel yang berjudul Assalamualaikum Calon Imam karya Ima Madaniah.

\section{PEMBAHASAN}

Di dalam novel ini juga terdapat nilai-nilai pendidikan karakter yang dapat diterapkan dalam kehidupan sehari-hari. Ada beberapa aspek pendidikan karakter yang perlu diteladani.

a Pengetahuan Moral

Ada beberapa jenis pengetahuan moral yang berkaitan dengan kehidupan. Terdapat enam aspek yang utama dalam pendidikan karakter sebagai berikut:

1) Kesadaran moral

Kesadaran Moral mengacu pada kesadaran diri sendiri terhadap suasana yang dilakukan seseorang baik untuk dirinya sendiri maupun orang lain, novel ini menggambarkan suasana di dalam bus yang terlihat padat sampai ada yang tidak kebagian kursi, kursi duduk diprioritaskan untuk orangtua atau ibu hamil. Sehingga orang yang lebih muda harus mengalah untuk berdiri.

"Stiker yang ditempel di kaca jelas menunjukkan bahwa kursi duduk diprioritaskan untuk ibu hamil, ibu yang menggendong anak-anak, orang tua, dan penyandang cacat. Dia kategori yang mana? Dari seragamnya jelas sekali bahwa dia anak SMA, tapi dia duduk dan bersandar dengan santai." Seharusnya yang lebih muda harus mengalah, lebih baik berdiri daripada duduk dan membiarkanya begitu saja tanpa memikirkan orang lain, remaja sebaiknya berfikiran yang positif dan mampu menunjukan kesadaran moral yang tinggi terhadap lingkunganya.

\begin{tabular}{ccc}
\multicolumn{2}{c}{ Kesadaran moral mengenai } \\
tindakan yang dilakukan Nafisya
\end{tabular} menolong korban kecelakan di jalan dalam posisi darurat dan membawa korban ke rumah sakit, awalnya Nafisya hendak berangkat ke panti asuhan yang sedang ada acara dengan transportasi bus, bus melaju dengan lancar tetapi setibanya dijalan raya bus berhenti dan tidak bisa jalan karena di depan ada mobil berlalu-lalang yang terlibat kecelakaan.

Nafisya tanpa pikir panjang turun dari bus dan ingin menolong korban kecelakaan karena dia juga ikut anggota PMI, jiwa kepeduliaan terhadap orang lain muncul. Ada anak kecil yang butuh pertolongan dan harus segera dibawa ke rumah sakit. Saat ia menolong korban yang harus segera ditangani dokter ia tanpa pikir panjang menandatangi surat penanggungjawab pasien karena Nafisya ingin anak itu segera ditangani oleh dokter, tetapi kakak Nafisya yang bekerja di rumah sakit itu kaget ketika ada korban kecelakaan yang mendandatangani sebagai penanggung jawab adalah Nafisya. Ayah korban tidak terima sehingga kakak Nafisya sangat marah terhadapnya hingga menanparnya, karena Fisya berpikir urusanya di rumah sakit cepat selesai dengan mendatanganinya, kalau menunggu orangtuanya akan lama dan kasihan dengan anak itu. Lama-kelamaan Kakak Nafisya mengetahui apa yang sebenarnya teradi dan meminta maaf kepada Nafisya "Kakak minta maaf sama kamu, buat semuanya.... yang Kakak 
lakuin di rumah sakit, semua murni karena Kakak khawatir sama kamu, Sya."

"Rekaman kedurhakaanku selama ini terbayang di benak. Air mataku meluap semakin banyak. Hatiku mencelos. Aku tak pernah mengajaknya bicara, bahkan untuk sekadar memanggilnya "Abi" saja tak pernah kulakukan. Aku selalu menghindar jika akan bertemu dengannya. Mendengar namanya saja sudah membuatku muak. Hal yang kulakukan itu berbalik menusukku hari ini. Aku menangis memeluk lutut di kursi tunggu." Nafisya begitu menyesal telah memperlakukan Abinya seolah-olah orang lain dan bukan orang tuanya ia sangat benci terhadap ayahnya akibat perceraian orangtua di masa kecilnya, Nafisya belum tau apa-apa sudah ditinggal pergi Abi. Perasaan benci tumbuh hingga ia dewasa hingga ia menemukan titik terang yang menyebabkan Abinya meninggalakan keluarganya. Nafisya sangat menyesal dan ingin memperbaiki hubungan baik terhadap Abinya.

Permasalahan-permasalahan yang dihadapi seseorang memiliki tingkat yang berbeda-beda sehingga sebagai orangorang yang memiliki kesadaran moral yang baik hendaknya mementingkan urusan bersama daripada urusan pribadi, karena manusia hidup tidak sendiri melainkan dengan orang lain yang ada di sekitarnya pasti akan membutuhkan orang lain untuk menolongnya. Jika berbuat kesalahan hendaknya meminta maaf, apabila membenci sesuatu hendaknya melihat dari sisi baiknya karena segala sesuatu mempunyai resiko yang harus bisa dihadapi.

2) Mengetahui nilai moral

Nilai moral yang dapat diketahui di dalam novel ini seperti tanggung jawab, menghargai perbedaan, kejujuran, disiplin, toleransi, keadilan, penghormatan, intregritas, kebaikan yang sudah menjadi kebiasaan atau rutinitas sehari-hari. Akibat perceraian orang tuanya Nafisya memikirkan sesuatu yang dialami oleh kakaknya saat ini yang belum bisa berhijab, padahal semua wanita diwajibkan untuk menutup aurat dan menutup seluruh tubuh dengan berhijab. Hal ini disebabkan karena adanya trauma yang dialami Fisya dan Kakaknya akibat perceraian orangtua. "Kak Salsya turun dari lantai atas. Dia tampak anggun dalam balutan dress biru langit yang panjangnya hingga di bawah lutut. Sayang disayangkan dia tidak memakai jilbab. Mungkin Kak Salsya juga trauma terhadap perpisahan Abi dan Ummi." Sejak kecil Salsya dan Nafisya berpisah karena perceraian orang tua Salsya ikut Abi dan Nafisya ikut dengan Umi. Tetapi beberapa tahun kemudian Salsya ikut tinggal bersama Uminya dan Nafisya.

Nafisya awalnya membenci Abi karena Abi menceraikan Umi dan memilih menikah dengan $\mathrm{Bu}$ Mia. Tapi, Fisya salah faham. Ternyata, Abi menikah dengan $\mathrm{Bu}$ Mia karena permintaan Umi sendiri. Bu Mia saat itu mengandung anak kembar, dan suaminya $\mathrm{Bu}$ Mia itu kembaran Abi yang sudah meninggal, suami $\mathrm{Bu}$ Mia memberikan pesan pada Abi untuk menikahi Bu Mia. Jadi Umi minta Abi menikahi Bu Mia. Sejak saat itu Fisya kembali menyayangi Abinya, Husein Akbar.

Wanita muslim diwajibkan untuk menutup auratnya "Itu yang kurang. Dia gak pake jilbab. Perintah Allah aja dia langgar, apalagi nanti kalo ane jadi suaminya." Percakapan antara Alif dan Kahfa membicarakan tentang Salsya yang belum memakai hijab. Kahfa ingin menjodohkanya dengan Alif, namun Alif tampak ragu-ragu karena Salsya tidak mengenakan hijab.

Pandangan tentang wanita muslim harus berhijab itu benar, maka Alif 
berkata seperti itu. Setiap orang mempunyai kepercayaan masing-masing, sehingga perubahan itu pasti ada tetapi ada prosesya tersendiri dan tdak bisa instant, harus memiliki keyakinan yang kuat.

3) Penentuan perspektif

Kemampuan untuk melihat situasi yang ada, membayangkan bagaimana berpikir, bereaksi, dan merasakan adanya permasalaan. "Jangan mendahului takdir Allah." Aku tidak suka diperlakukan seperti itu. Siapa yang tidak suka dipasang-pasangkan dengan orang yang kita suka? Itu semakin membuat perasaan ini tak mau pudar. Aku sudah lelah berharap terhadap makhluk. Hanya Allah satu-satunya yang pantas dijadikan tempat pengharapan." Apa Allah masih cemburu padaku sampai rasa sakitnya menjalar ke seluruh tubuh? harusnya tidak seperti ini. Sejak awal, keputusan menjatuhkan harap itu memang salah. Aku sedang berusaha menerima semuanya, termasuk keputusan Jidan untuk melamar kakakku.

Ketidakpercayaan Fisya terhadap seorang pria semakin menjadi-jadi membuat separuh jiwanya seakan putus asa jika berdekatan dengan seorang pria. Fisya menyukai sahabatnya bernama Jidan. Cinta itu ditujukan untuk Jidan tentangga dan teman bermainnya di masa kecil. Sayangnya kisah cinta ini harus berakhir. Jidan memilih wanita lain sebagai pelabuhan cintanya. Jidan menyukai kakaknya Fisya, yaitui Salsya Sabila Akbar.

Permasalahan demi permasalahan yang dilalui Nafisya masih berkecamuk dipikiranya akibat ia merasa tidak adanya keadilan. Semakin ia rasakan beban penderitaanya semakin banyak pertanyaan-pertanyaan berkecamuk dipikiranya. Adanya masalah-masalah tersebut dapat dilalui Nafisya dengan
Penuh kesabaran dan tidak lupa dengan Allah.

4) Pemikiran moral

Pemahaman apa yang dimaksud dengan moral dan mengapa harus aspek moral sebagai tindakan. Fisya hampir hendak mencekik pria di depanya. "Aku hampir hendak mencekik pria di depanku ini. Sepertinya dia masih duduk di bangku sekolah menengah dan belum memahami tahap-tahap penyelamatan bahwa semua korban harus dianggap tengah kritis." Anak SMA yang juga ikut menjadi relawan dalam kecelakaan, tetapi ia tidak mengerti bagaimana cara menolong korban dalam pertolongan pertama. "Istirahat dan meninggal berlahan, begitu?! Kataku dengan nada sedikit meninggi."

Relawan yang masih pelajar itu tidak paham dengan apa yang dimaksudkan Nafisya sehingga membuatnya geram dan ingin adu emosi denganya karena hanya menyuruh diam, tenang dan sabar tanpa tindakan apa-apa, Saat tiba di rumah sakit Nafisya menyuruh suster untuk segera menanganinya "Tolong bilang sama dokternya untuk segera melakukan CT Scan. Korban mengalami pendarahan hebat di dekat lambung. Dia banyak kehilangan darah tadi, bibirnya sempet biru dan dia sudah mendapat suntikan dopamin." Nafisya segera membawanya ke rumah sakit agar segera dapat pertolongan dari dokter, jika berdepat dengan anak SMA tadi tidak akan selesaiselesai. Maka ia menghindari perdebatan itu.

Orang yang paling dimurkai Allah adalah orang yang selalu mendebat. Nafisya memicingkan mata tanda tidak ingin berdebat. segala sesuatu yang dibenci oleh Allah pasti mendaptakan hasil yang kurang maksimal. Segala sesuatu harus dikerjakan dengan kepala 
dingin dan tidak emosi agar semua beralan baik dan lancar.

5) Pengambilan keputusan

Mampu memikirkan seseorang dalam bertindak dalam melawan permasalahan yang dihadapi melalui permasalahan moral dengan cara ini merupakan pengambilan keputusan yang reflektif. Pengambilan keputusan yang diambil oleh tokoh utama yaitu Nafisya sangat efektif ia ingin menjalangkan solat lima waktu dan solat malam serta membaca quran serta menghafal disetiap kesendirianya "Daripada berdiri bosan, kuputuskan untuk memasang earphone mendengarkan murotal surah Al-Kahfi dengan volume paling kecil." dia juga sudah tidak membenci Abinya dan bersifat lebih baik terhadap keluarga Abi yang baru.

Pengambilan keputusan untuk pergi ke luar negeri untuk melupakan Jidan. "Aku memandang Ummi yang sudah tentu tidak rela jika aku pergi ke Eropa. Rida Allah ada pada rida orang tua. Jika Ummi berkata tidak, aku juga tidak akan pergi. Aku lebih menyayangi Ummi dibanding beasiswa itu." Nafisya tidak jadi pergi ke luar negeri karena Umminya tidak rela jika Nafisya pergi ke luar negeri sendirian tanpa ada teman-temanya yang mendampingi "Aku berniat berubah. Aku tidak mau membenci Abi dan keluarga barunya". Aku juga ingin terlepas dari filofobia yang menyiksaku; saat jatuh cinta mendadak tangan gemetar dan berkeringat tak jelas Nafisya membuat keputusan untuk mengubah doa di mana nama Jidan selalu kusebut di dalamnya.

Nafisya meminta agar ada seorang pria baik di antara yang paling baik yang mampu menjadi imamku kelak, membuat imanku sempurna, dan menuntunku sampai jannah-Nya, serta pengambilan keputusan tentang khitbah Alif dengan Fisya "Nafisya mengusap kedua kelopak mata lalu berkata,"Fisya udah punya jawaban buat Pak Alif." Dia menunduk dalam dan mengepal erat tangan yang gemetar."Fisya bersedia... Tapi Fisya mau, kita nikah sekarang di depan Abi," lamaran Alif diterima dan mereka menikah dihadapan Abinya yang sedang terbaring di ranjang rumah sakit, untuk memenuhi permintaan Abi, Fisya akhirnya menerima lamaran Pak Alif. Pernikahan terjadi, ditemani Kahfa, Huda yang menjadi saksi. Abi jadi wali, dengan mahar dari Pak Alif adalah hafalan surah Ar-Rahman. Setelah selesai Ijab Qobul, Abinya menghembuskan nafas terakhir.

Pengambilan keputusan yang diambil Nafisya sudah memiliki titik positif untuk memulai kehidupan yang sesungguhnya, pengambilan untuk pergi ke luar negeri untuk melupakan Jidan, serta pengambilan keputusan tentang khitbah Alif dengan Fisya diterima dan mereka menikah dihadapan Abinya yang sedang terbaring di ranjang rumah sakit. Keputusan yang diambil pasti untuk kebaikan ke depanya.

6) Pengetahuan pribadi

Mengembangkan pengetahuan moral pribadi menjadi menjadi sadar akan kekuatan dan kelemahan individual dan bagaimana caranya mengatasi kelemahan tersebut berdasarkan karakter. Fisya berada pada posisi banyak beban yang dipikirkan hingga ia tidak terkontrol dalam melakukan aktivitasnya, tetapi ia masih tetap dalam keadaan baik. "Allah bilang: "Apabila telah tiba waktunya (yang ditentukan) bagi mereka, tidaklah mereka dapat mengundurkanya barang sesaat pun," kata Nafisya dengan suara gemetar menahan tangis." Fisya gak masalah kalo harus menemui Allah besok." Fisya memasrahkan diri kepada Allah mengenai hal-hal yang berkecamuk dipikiranya karena sudah banyak bebn permasalahan yang dihadapinya. 
Manusia yang hidup pasti akan merasakan mati, semua alam semesta di dunia ini hanya milik Allah dan akan kembali pada Allah. Sebagai seorang muslim hendaknya untuk bersyukur, mentaati aturan, dan melaksanakan perintahNya dengan sebaik mungkin.

\section{b Perasaan Moral}

Aspek-aspek kehidupan emosional moral dalam pendidikan karakter adalah sebagai berikut.

1) Hati nurani

Hati nurani memiliki empat sisi yaitu sisi kognitif, mengetahui apa yang benar dan sisi emosional merasa berkewajiban untuk melakukan apa yang benar. Di dalam cerita Nafisya maupun wanita yang lainya harus memiliki jiwa yang baik, rendah hati, dan lemah lembut. "Banyak garis polisi yang sudah dipasang. Aku melihat beberapa orang menjerit di mana-mana, ketakutan dan panik, lengkap dengan korban yang berlumuran darah. Beberapa kali aku mengucapkan istirja'. Kaki dan tanganku gemetar. Sangat tidak manusiawi jika aku melintas begitu saja hanya untuk bisa terlepas dari kemacetan ini. Nafisya masih berada di dalam bus dan ia ingin segera lari untuk melihat kondisi korban yang harus mendpatkan pertolongan. Ia merasa tidak mungkin hanya berdiam diri di dalam bus dan tidak ikut terjun langsung di lokasi kecelakaan.

Kecelakaan itu mengakibatkan kemacetan yang sangat parah, padahal satu korban kecelakaan harus segera dibawa ke rumah sakit karena dalam kondisi lemah dan berlumuran darah. "Dia memakirkan mobil di pinggir jalan, keluar, membuka pintu belakang, menggendong anak itu, lalu membaringkanya di trotoar. Dia mengecek nadi anak itu kemudian menekan bagian jantung korban beberapa kali. Anak itu mengalami henti jantung. Mungkin karena suplai darah dalam tubuhnya benar-benar berkurang." Mobil pengendara yang ada paling depan menjadi sasaran membawa korban ke rumah sakit karena ambulan hanya ada dua masih dipakai semua, pengendara mobil bersedia membantu dan korban bisa segera dibawa ke rumah sakit.

Pembentukan jiwa sosial yang dilakukan dengan membantu sesama yang sedang mengalami kesulitan maupun di lingkungan tempat-tempat yang masih membutuhkan bantuan kita, seperti panti asuhan, dan lainya. Seseorang harus memiliki kebaikan yang dapat bermanfaat bagi diri sendiri maupun orang lain.

2) Harga diri

Memiliki harga diri maka tidak bergantung terhadap persetujuan orang lain. Membentuk harga diri berdasarkan nilai-nilai seperti tanggung jawab, kejujuran, dan kebaikan. "Acara diawali dengan membaca Alquran bersama lalu serah terima sumbangan secara simbolis. Acara dilanjutkan dengan makan bersama dan bermain bersama anak-anak yatim. Kami juga saling sharing dengan anak-anak panti yang sudah beranjak dewasa". Begitu menakjubkan mendengar seberapa jauh hafalan Alquran mereka. Hal itu membuat iri dan bertanya-tanya, apa kabar hafalanku?" Pembentukan jiwa madani yang dilakukan dengan mengadakan acara amal dan sosialisasi di temapat-tempat yang masih membutuhkan bantuan seperti panti asuhan, dan lainya. Seseorang harus memiliki kebaikan yang dapat bermanfaat bagi diri sendiri maupun orang lain serta memperbaiki diri sendiri dengan melaksanakan solat lima waktu dan sering membaca Alquran.

"Ada yang bilang jadi muslimah itu harus anggun dan lemah lembut, apalagi setelah berhijab." Seorang muslimah 
yang nantinya jadi ibu haruslah lemah lembut. Namun, muslimah juga harus bisa melindungi diri. Rasulullah bahkan mengajarkan Aisyah cara memanah jangan mau menjadi muslimah yang dicap lemah. Muslimah harus bisa menjadi kuat dan tangguh.

Pembentukan harga diri berawal dari diri sendiri dalam melakukan aktivitas sehari-hari, memiliki rasa tanggung jawab yang penuh, seperti di dalam cerita untuk lebih mementingkan harga diri.

3) Empati

Empati merupakan identifikasi dengan, atau pengalaman yang seolaholah terjadi dalam, keadaan orang lain. Empati memampukan kita keluar untuk dari diri kita sendiri dan masuk ke dalam diri orang lain. Alif berhenti lagi seolah ada sesuatu yang menahan langkahnya. Dia menoleh pada Nafisya."Sya," Suaranya terdengar begitu lembut dan pelan membuat Nafisya sedikit mengangkat kepala karena mengira Alif sudah berjalan cukup jauh." Tanda kecintaan Allah pada hamba-Nya adalah dengan mengujianya. Jangan terlalu membenci suatu masalah. La tahzan. Innallaha ma'ana,"

Sementara itu, Nafisya yang tejebak dengan sang stylish sedang mencoba sepatu tinggi putih." Hijrah memang sulit, Mas. Tapi yang lebih sulit itu istiqomah. Kita bisa berubah jadi baik, tapi sulit untuk terus-menerus istiqomah berbuat baik. Perempuan seperti Rachel itu bukan harus dijauhi, justru didekati dan diajak pada kebaikan. Ingatkan bahwa apa yang dilakukanya itu salah. Kodratnya sebagai perempuan, bukan sebagai laki-laki.

Cerita dari mas boutiqe dan Rachel yang bergaya tidak sesuai dengan kodratnya, sebagai Nafisya yang menjadi penengah, dapat memberikan motivasi terhadap keduanya untuk memperbaiki kesalahan dan melaksanakan apa yang sudah menjadi kodratnya, berubah untuk lebih baik lagi.

4) Mencintai hal baik

Ketika orang-orang mencinatai kebaikan maka mereka akan senang melakukan kebaikan. Memiliki moralitas keinginan, bukan hanya moral tugas. Sosok tokoh utama dalam novel juga mempunyai kecintaan baik seperti mencintai Alquran dan mengerjakan solat lima waktu. "Terima kasih, ya Allah, salah satu nikmat-Mu yang selalu lupa kusyukuri, yaitu teman-teman yang baik dan saleh. Memang, akan selalu ada orang yang membuatmu bersedih, dan akan selalu ada Allah yang membuatmu tertawa." Nafisya sangat bersyukur atas apa yang sudah ia miliki karena banyak orang-orang yang sangat perhatian kepadanya dikala senang maupun susah.

Teman-teman kuliah begitu perhatian dan baik, sosok Alif sebagai imamnya, Umi dan Abi, Kak Salsya, Mbak Nayla begitu baik, Fadli dan Fadil juga tak kalah baik.mereka menganggap Nafisya sebagai anak bungsu yang patut dilindungi. Apalagi Tante Mia, dia sampai membuat makanan kesukaan Nafisya untuk dibawa ke rumahnya. Entahlah

"Suara lantunan ayat Alquran yang kusukai lagi-lagi terdengar dari lantai bawah. Aku merasa semakin tenang dan betah berdiam diri di sini. Sudah lama aku mengagumi suara yang entah milik siapa. Ya Allah, aku merasa iri karena ada pria yang membaca surah-Mu dengan begitu indah. Suatu saat nanti aku akan minta pada pria itu untuk membacakan surah Ar-Rahman." Suara yang indah menyelimuti santero masjid kampus yang beberapa kali terdengar di telingganya. Suara itu sangat indah. Nafisya berharap suatu saat nanti ada yang membacakan surah Ar-Rahman ketika ia menikah. 
Beribu syukur kupanjatkan karena Allah menggratiskan oksigen yang setiap detik, menit, jam dihirup oleh manusia. Kebaikan yang ditanam seseorang pasti akan mendapatkan kebaikan yang lebih baik dari kebaikan sebelumnya, dari kebaikan-kebaikan yang meliputi rasa syukur Nafisya terhadap sesuatu yang membawanya untuk tetap memiliki rasa rendah hati dan selalu mentaati perintahNya dan menjauhi larangaNya.

5) Kerendahan hati

Kerendahan hati merupakan sisi afektif pengetahuan pribadi. Keterbukaan yang sejati terhadap kebenaran dan keinginan untuk bertindak guna memperbaiki kegagalan. Dalam sebuah cerita yang berkitan dengan kehidupan sehari-hari Fisya memiliki sifat rendah hati terhadap semua orang. "Bukan Nafisya namanya kalau sampai kehabisan akal. Aku melepas handsock yang kugunakan." Perjalan menuju rumah sakit dalam kondisi mobil melaju sangat kencang, tanpa sengaja bahu Alif lecet terkena sandaran kursi. Ketika melihat lengan Alif terluka bersimbah darah, Nafisya tak kehilangan akal untuk melepas handshocknya untuk membalutkanya di lengan Alif yang terluka agar darah tidak keluar terus-menerus sampai di rumah sakit nanti.

Hati Alif memang melimpah untuk Nafisya. Baginya, itu suatu tanggung jawab yang berat. Manusia diuji dalam dua bentuk: menghadapi kesulitan atau menghadapi kelapangan. Karya harta adalah ujian. Satu hal yang Alif takutkan, yaitu dia tidak bisa mempertanggungjawabkan semuanya di hadapan Allah pada hari perhitungan kelak. Alif memang keturunan dari keluarga yang berada mempunyai rumah mewah, mobil, ia sebagai dokter sekaligus menjadi dosen karena ia ingin membantu orang lain yang yang sedang sakit namun tidak memiliki biaya serta sebagai dosen untuk menyalurkan ilmu yang ia miliki kepada mahasiswanya.

Kerendahan hati yang dimiliki sosok Nafisya dan Alif sebagai hasil dari perjuanganya dahulu dalam menjalani kehidupan yang penuh dengan lika-liku, dengan disertai doa dan tetap menjadikan Allah sebagai penolongnya. Maka ia dapat mencapai keinginan untuk memiliki kehidupan yang lebih baik.

c Tindakan Moral

1) Kompetensi

Kompetensi moral memiliki kemampuan untuk mengubah penilaian dan perasaan moral ke dalam tindakan moral yang efektif. Untuk memecahkan suatu permasalahan secara adil sama halnya pada saat "Ummi menatapku heran, begitu pun Kak Salsya dan Jidan. Pasalnya roti di piringku belum habis dan tidak biasanya susu cokelat diminumnya." Nafisya sangat menutupi perasaanya terhadap Jidan hingga ia tidak ingin bertemu dengan Jidan lagi karena hal itu akan membuatnya semakin sakit.

Fisya menyukai sahabatnya bernama Jidan. Cinta itu ditujukan untuk Jidan tentangga dan teman bermainnya di masa kecil. Sayangnya kisah cinta ini harus berakhir. Jidan memilih wanita lain sebagai pelabuhan cintanya. Jidan menyukai kakaknya Fisya, yaitui Salsya Sabila Akbar. Namun hati Jidan masih ragu-ragu untuk menikahi Salsya, sebab sebagian hatinya yang lain ada untuk Fisya. Ia binggung dengan keputusan yang telah diambil, tetapi Jidan tetap menikah dengan Salsya

Sarapan pagi sebagai rutinitas bersama Ummi dan Kak Salsya setiap pagi, karena ada sosok Jidan yang datang tiba-tiba membuat Nafisya tidak berselera untuk sarapan. Ia segera berangkat untuk pergi di acara santunan panti asuhan. Fisya mengambil napas 
panjang, bermaksud menenangkan diri. Aku harus yakin jika ingin melakukan kebaikan. "Bismillah, hanya Engkau sebaik-baiknya penolong, yaa Rabb. Aku berusaha menemukan pembuluh vena dalam leher anak tersebut. Posisisi vena di leher anak-anak lebih mudah ditemukan. Setelah menyuntikkan obat tersebut, aku bisa sedikit bernapas lega."

Kulihat pria itu juga mengucapkan syukur karena dada anak tersebut kembali naik turun meskipun masih belum sadarkan diri. Peristiwa kecelakaan yang melibatkan satu korban anak-anak yang di bawa Nafisya dan Alif menuju rumah sakit. Tetapi di dalam perjalanan korban kehilangan denyut nadi sehingga mobil harus berhenti di pinggir jalan dan melakukan upaya penyelamatan.

Upaya penyelamatan korban kecelakaan terus dilakukan Nafisya dan Alif. Nafisya sebagai mahasiswa Farmasi sedikit mengerti tentang penyelamatan korban tetapi Alif lebih mengerti karena ia sebagai dokter. Nafisya tidak tahu bahwa Alif seorang dokter akibatnya Alif dan Nafisya bersitegang dalam penyelamatan korban karena dalam kondisi darurat dan segera membutuhkan pertolongan. Akhirnya korban bisa bernafas dengan baik lagi lalu segera menuju rumah sakit untuk mendapatkan pertolongan.

Kejadian yang dialami di atas dapat disimpulkan bahwa kompetensi dalam suatu permasalahan dapat diselesaikan dengan baik apabila seseorang samasama memiliki jiwa sosial yang tinggi. Peristiwa kecelakaan maupun peristiwa yang lainya dapat diselesaikan dengan sikap tenang walaupun dalam kondisi darurat, agar dapat berpikir positif dan memiliki ide untuk mengatasinya serta adanya tindakan yang nyata.

2) Keinginan
Keinginan untuk menjaga emosi di bawah kendali pemikiran. Keinginan untuk melihat dan berfikir melalui seluruh dimensi moral. Dalam keinginan dalam cerita menggambarkan keinginan yang lebih baik bagi Fisya maupun yan lainya. "Fisya tidak kebagian waktu salat berjamaah karena harus berjalan kaki untuk bisa sampai ke masjid universitas. Satu jam selanjutnnya kuhabiskan untuk melanjutkan hafalan di lantai dua." Menghafal merupakan salah satu cara melupakan sesuatu. Cara menghafal melalui suara akan cepat menghafal dengan baik karena di dalam pikiran hanya penuh dengan ayat-ayat Allah.

Setelah pernikahan Alif selalu membimbing Fisya menjadi istri yang baik. "Alif sudah bernazar bahwa jika Nafisya sadar, dia akan mengundang seratus anak yatim ke rumah mereka untuk makan-makan. Nazar itu diwujudkan hari ini. Bahkan, anak yatim yang datang lebih dari seratus. Tentu saja Alif tak menyuruh Mbok Lin untuk memasak makanan. Dia memesan makanannya agar lebih cepat." Fisya diam-diam menyimpan rahasia besar.

Fisya berpura-pura bahagia di depan Alif. Padahal di dalam hatinya merasakan sakit yang amat dalam. Akhirnya Alif tau kebohongan Fisya. Dia tidak melanjutkan sekolah ke Jerman tetapi ia berobat di rumah sakit dan menyembunyikan penyakitnya. Alif masih belum mengetahui kalau Fisya menyembunyikan penyakit yang diidapnya., Fisya kehilangan penglihatan dan pendengaranya yang semakin semakin melemah.

Alif diberi tahu Jidan tentang penyakit Fisya. Dia menghampiri kamar inap Fisya. Fisya buta sementara dan hanya bisa duduk dikursi roda, Alif menghampiri Fisya dan sudah mengetahui semuanya, cintanya semakin erat. Alif berkeinginan untuk 
memperbaiki hubungan dengan Fisya dengan ikatan pernikahan, Walaupun Fisya kesehatanya tidak seperti sediakala, tetapi keluarganya sangat menyayanginya.

Setelah Nafisya keluar dari rumah sakit nazar yang dulu terucap akhirya dapat diwujudkan, keinginan Alif dikabulkan oleh Allah untuk mendatangkan anak-anak yatim di rumahnya untuk mendoakan kesembuhan Nafisya.

3) Kebiasaan

Orang-orang yang memiliki karakter yang baik yakni ia melakukan hal yang baik karena suatu dorongan kebiasaan. Kebiasaan ini akan memunculkan karakter yang baik. Mulai dari kebiasaankebiasaan yang dilakukan sehari-hari dari kebiasaan baik hingga kebiasaan buruk. Alih-alih melupakan urusan dunia sejenak, hal membuatnya terjebak dengan pekerjaan. Tak masalah. Baginya semua hal itu "Lillah. Jadikan kegiatan itu ibadah dan jadikan setiap ibadah itu ikhlas."

Perkuliahan awal dengan dosen baru sudah dimulai, karena terburu-buru inilah yang ditakutkan Nafisya. "Ma-maaf, Pak, makalah saya tertinggal," kataku gugup. Aku bukan anak pemalas. Aku tidak tahu kenapa makalah itu tidak ada di dalam tas. Entah kenapa aku juga sering datang terlambat meskipun berangkat satu jam sebelumnya. Selalu ada halangan menghadangku di perjalanan." Tugas makalah yang seharusnya dikumpulkan dengan dosen baru itu tertinggal di rumah. Nafisya harus menerima risiko yang akan terjadi yaitu memintanya untuk detensi. Kebiasaan Nafisya tidak hanya di kampus saja, di rumah juga melakukan kebiasaan yang serupa."Ummi datang dari arah dapur."Astaghfirullah, Nafisya!" Katanya. "Kamu cerobohnya jadi kebiasaan."
Kecenderungan melakukan kebiasaan-kebiasaan baik maupun buruk yang dialami Nafisya tidak bisa diprasangka melakukan kebiasaan yang negatif karena ketika Nafisya terlamabat masuk kuliah disebabkan karena adanya sesuatu membantu orang lain ketika sedang membutuhkan pertolonganya serta kebiasaan yang dilakukan di rumah juga masih dalam kebiasaan yang positif. Kebiasaan Nafisya memiliki hasil positif karena ia mau mengorbankan dirinya sendiri untuk orang lain.

\section{PENUTUP}

Berdasarkan pembahasan yang telah dipaparkan, penulis memaparkan novel Assalamualaikum Calon Imam karya Ima Madaniah terdapat pendidikan karakter sebagai berikut: Kesadaran moral, Mengetahui nilai moral, Penentuan perspektif, Pemikiran moral, Pengambilan keputusan, Pengetahuan pribadi. Perasaan Moral; Hati nurani, Harga diri, Empati, Mencintai hal baik, Kerendahan hati. Tindakan Moral; kompetensi, keinginan, kebiasaan. Ada beberapa jenis pengetahuan moral yang berkaitan dengan kehidupan. Terdapat enam aspek yang utama dalam pendidikan karakter sebagai berikut: Kesadaran moral, Mengetahui nilai moral, Penentuan perspektif, Pemikiran moral, Pengambilan keputusan, Pengetahuan pribadi Aspekaspek kehidupan emosional moral dalam pendidikan karakter adalah sebagai berikut: Hati nurani, Harga diri, Empati, Mencintai hal baik, Kerendahan hati. Tindakan Mora meliputi Kompetensi, Keinginan, Kebiasaan

Daftar pustaka

Madaniah, Ima. Assalamualaikum Calon Imam. Jakarta: Coconut Books, 2017.

Natalia Sunata, Yanuri, Kundharu Saddhono, and Sri Hastuti. 
“TINJAUAN STRUKTURAL DAN NILAI PENDIDIKAN NOVEL BIDADARI-

BIDADARI SURGA KARYA TERE

LIYE: (Relevansinya Dalam

Pembelajaran Di Sekolah Menengah

Atas)." BASASTRA Jurnal Penelitian

Bahasa, Sastra Indonesia Dan

Pengajarannya. 1, no. 3 (2014).

Raka, G, Y Mulyana, S Markam, and

Semiawan CR. Pendidikan Karakter

Di Sekolah: Dari Gagasan Ke

Tindakan. Jakarta: Gramedia, 2011.

Stanton, R. Teori Fiksi. Yogyakarta:

Pustaka Pelajar, 2007. 
24| 2020 